\title{
Effect of Teaching Guidelines on Knowledge, Attitudes, and Practices Regarding COVID- 19 among the First Year Nursing Students
}

\author{
Rehab Ragab Bayomi ${ }^{1} \&$ Nadia Mohamed Taha ${ }^{2}$ \\ ${ }^{1 .}$ Lecturer of Medical Surgical Nursing, Faculty of Nursing, Zagazig University, Egypt \\ 2. Professor of Medical Surgical Nursing, Faculty of Nursing, Zagazig University, Egypt
}

\begin{abstract}
Background: The World Health Organization has declared Coronavirus Disease 2019 (COVID-19) a pandemic. Controlling its spread is being attempted at both the global and national levels. Aim: the aim of this study was to determine the effect of teaching guidelines on knowledge, attitudes, and practices regarding covid19 among the first year nursing students. Subjects and method: Aquasi experimental design with pre -post assessment was used to conduct the study. Setting: The study was conducted at Faculty of Nursing, Zagazig University. Subject: Students in first year at Faculty of Nursing, Zagazig University (286 from 800 students). Tool: data collected, by used an Interview form: included student's characteristics, COVID-19 knowledge, questions regarding attitudes toward COVID-19, as well as preventive measures and infection control about personal hygiene and infection control, an observational checklist regarding technique of using mask, and hand-washing. Results: There was a significant improvement of student's knowledge score post guidelines. Also there was a significant improvement of their practice, and the majority of them had positive attitude toward COVID-19. Conclusion, there was a strong positive correlation between total student's knowledge, attitude, and their reported practice regarding COVID-19 with highly statistically significant differences $(\mathrm{P}=000)$. Recommendation, Application of the current Coronavirus preventive health programs at all other nursing faculties in Egypt to raise their knowledge and enhance their attitude.
\end{abstract}

\section{Keywords: Attitude, COVID-19, Knowledge, Nursing Student, Practice \&Teaching Guidelines}

\section{Introduction}

COVID-19 is a novel viral disease caused by severe acute respiratory syndrome coronavirus (SARS-CoV2) that was discovered in Wuhan, Hubei Province, China in 2019. (Chen, et al, 2020). The corona virus disease (COVID19) outbreak had been confirmed in over 210 countries and territories as of May 31, 2021. Around 171 million people had been infected by the virus, and over 3,5 million people had died as a result. The United States, Brazil, and India are among the most severely affected countries (World Health Organization, 2021). In response to this critical situation, the World Health Organization (WHO) declared COVID-19 a public health emergency of international concern on January 30 and urged all countries to work together to prevent the virus's rapid spread (World Health Organization, 2020).

The symptoms of this contagious disease include dry cough, fever, anosmia (loss of smell), weakness, headache, body pains, vomiting, sore throat, and respiratory difficulty, and the onset of symptoms ranges from 1-14 days. After contracting the virus, some infected people remain asymptomatic (without symptoms), whereas the majority of symptomatic cases are mild to moderate, with around $10 \%$ being serious (Okoro, et al, 2020).

While all age groups can equally contract the virus, the elderly are particularly susceptible. Obesity, underlying medical disorders like diabetes, systemic hypertension, and other cardiac pathologies, and immune-compromising diseases like HIV infection are also risk factors. Similarly, these people's mortality rates have been shown to be higher. (Zhang, et al., 2020).

After all, according to the World Health Organization, 2020 (WHO), the most important preventive measures are as follows: Maintain a physical distance from other people (at least 3 feet or 1 metre): After touch with the respiratory tract, the hands must be washed immediately: Keep your hands away from your eyes, nose, and mouth: Environmental and other constantly touched surfaces should be cleaned and disinfected on a regular basis: improve living space airflow by opening as many windows and doors as possible: fever, cough, and difficulty in breathing seek immediate treatment.

Knowledge, Attitude, and Practice (KAP) is a critical cognitive factor in health prevention and promotion in public health. It requires a number of beliefs about the disease's causes and exacerbating factors, as well as identification of symptoms, and available methods of treatments and consequences. Beliefs about COVID19 come from variety of sources, such as stereotypes concerning similar viral diseases, governmental 
records, social media and the internet, prior personal experiences, and medical sources. The efficacy of these beliefs can affect different preventive behaviors and can vary by population. In certain cases, a lack of expertise, or if the majority of medical-related beliefs are misconstrued or incorrect, can pose a significant threat (Zannatul, et al, 2020).

To assist in the eradication of COVID-19, it is important to investigate the level of nursing students' awareness of COVID-19 at this critical time. The disease's knowledge, attitude, and practices (KAP) have an effect on students' dedication to preventive measures. (Alshdefat, et al, 2021).

\section{Significance}

Virus outbreaks and an increasing death rate have affected daily life in Egypt. In Egypt, the coronavirus is considered pandemic as part of a worldwide corona virus pandemic. The first case of Covid-19 in Egypt was confirmed by the Ministry of Health and Population Egypt on February 14, 2020. (Minsitry of Health and Population Egypt, 2020) According to the World Health Organization 2021, the coronavirus pandemic spread rapidly across the world, with 180,640 confirmed cases of COVID-19 and 10,541 deaths in Egypt between January 3 and February 2021. It is important to investigate the level of COVID-19 knowledge among nursing students at this critical time in order to help in the eradication of COVID-19. Students' knowledge, attitudes, and practice (KAP) about the disease have an effect on their contribution to preventive measures. In this study we evaluate effect of nursing guidelines on knowledge, attitudes, and practices toward covid19 among the first year nursing students.

\section{Aim of the study}

The aim of this study was to determine the effect of teaching guidelines on knowledge, attitudes, and practices regarding COVID-19 among the first year nursing students. Through the following objectives:

1- Assess students' knowledge, attitudes, and practices pre and post implementing teaching guidelines.

2- Design, implement, and evaluate the effect of implementing teaching guidelines on students' knowledge, attitudes, as well as practices regarding COVID 19.

Research hypothesis:

The current study hypothesized that

H1: Implementation of teaching guidelines will lead to statistically significant improvement in students related to knowledge and attitude regarding COVID19 than before.

H2: Implementation of teaching guidelines will lead to statistically significant improvement in COVID-19 preventive and hygienic care practice for students than before.

\section{Subjects and Methods}

Research design:

The study was carried out by using quasi experimental design with pre -post assessment. Setting

The study was carried out at Faculty of Nursing, in Egypt, Sharkia governorate's Zagazig University.

Subject

Convience sample used to achieve aim of the study. It includes 286 first Year University Students were the target group from Faculty of Nursing, Zagazig University

The sampling size was determined by using Epi-info 7 software (Dean, et al., 1995). As there were no similar studies related to coronavirus disease, the calculations were based on assumption that the probability of having good knowledge on and positive attitudes toward preventive measures and personal hygiene against coronavirus disease. Total of students was 800 students. A minimum sample size of 260 was estimated to reflect this population at a 95 percent confidence level. The researchers chose this year's sample because it is important to carry out preventive measures to prevent the spread of this infection. 286 students were selected randomly, and interviewed by the researcher.

Tools and technique of data collection

The researchers used two tools: tool one: an Interview form: was designed and implemented by the researchers. It divided into three parts. The first part included student's characteristics while the second covered COVID-19 knowledge. Third part questions regarding attitudes toward COVID-19, as well as preventive measures and infection control which has two parts a): contains 11 practical items about personal hygiene and infection control while part $b$ constitutes an observational checklist regarding technique of using mask, and hand-washing.

Tool I: was designed and implemented by the researchers. It divided into three parts:

The first part included characteristics of students e.g age, sex, residence, history of chest disease, and immune disease history, smoking, and source of information about COVID-19

The second part covered knowledge about corona virus, it was adapted from Ministry of Health guidelines $\mathbf{2 0 2 0}$ composed of 27 close ended questions which included corona virus's nature, signs and symptoms associated to corona virus, risk group for corona virus disease, mode of transmission, vaccination and treatment, and prevention measures and self-protection. This tool was utilized twice before and after implementation of teaching guidelines in order to evaluate student's acquisition of knowledge regarding corona virus. 
Knowledge concerning COVID19 was assessed by answering 27 true and false questions followed by calculation of a total cumulative knowledge score for each participant. Total score of knowledge was 27 grades $(100 \%)$; the true answer was scored one and zero for false and unknown answers. Knowledge was considered satisfactory if the percent score was equal or above $60 \%$ and unsatisfactory if less than $60 \%$ based on statistical analysis and students' knowledge regarding corona virus.

Third part questions regarding the attitudes toward COVID -19: It determines attitudes of students before and after implementation of teaching guidelines. It was adapted from (Nassef, et al.,2020) it contains 18 closed ended questions in which students' responses were evaluated via a two point likert scale of agreement. students who choose agree receive one grade while those choose disagree will take zero degree with total score (18 degree), then students who obtained 60 or more takes positive attitudes and who obtained less than 60 takes negative attitudes.

Tool II: Preventive measures and infection control Which constitutes two parts: The first contains of 11 practical items related to personal hygiene and preventive measures which had only two probabilities either done or not done, which given scores as follows: done was given score one and not done was given score of zero, second part constitute observational checklist: it was developed to assess student's performance in relation to techniques of using and taking off a face mask which contains 12 items, and performance related to hand wash which contains15 items. This tool adopted from (WHO, 2020). Each step that was done received a score of one, while those that were not done received a score of zero. A percent score was computed by adding the scores from each step in the procedure. The overall score (38 grades $(100 \%)$ the students considered had satisfactory level of practice when total score equal or above $60 \%$ and unsatisfactory if it below $60 \%$ based on statistical analysis and importance of students practice regarding preventive measures and infection control of corona virus.

\section{Tool's Validity and reliability:}

The designed tools and booklet were tested for content validity to see whether they covered the aim or not. It was developed by a panel of seven medical surgical nursing experts who modified the tools for content, clarification, relevance, comprehensiveness, and ease of use. Minor modifications were implemented, according to their opinions.

Reliability: The Cronbach test and retest were used to measure tool reliability. It was used to ensure that the questionnaire was internally consistent. It was discovered that the values were $0.988,0.985$, and
0.977 for each one consecutively.

Pilot study:

A pilot study was conducted on 29 students (10\% of the total sample) who were not included in the main study. They were selected to assess the tools' applicability, clarity, and simplicity, as well as, to determine the time devoted to data collection. Clarification and estimation of the time needed for filling the study tools, and testing the feasibility of the research process needed modifications were carried out based on the results of the pilot study to develop final form of the tool.

Ethical consideration:

Each potential participant was told about the nature, purpose, and benefits of the study during the initial interview, and they were informed that their participation was voluntary. Subjects' confidentiality and anonymity were also guaranteed, with the data and knowledge gathered being kept private and only used for research purposes.

\section{Field work}

The data was collected for three consecutive months, from October 2020 to December 2020. After explaining the study's purpose, the presidents submitted their approval to conduct it. The study was split into two phases.

First phase: Focused on improving Students' knowledge of COVID-19. This was accomplished in three phases:

First phase (Assessment phase): The aim of the first phase was to evaluate the student's knowledge, attitude, and practice regarding COVID-19, as well as personal data, using assessment tools 1 , and 2 .

Second phase (Implementation phase): The aim of this phase is to improve the knowledge and attitude of first-year nursing students about COVID-19 prevention and controlling measures. The developed teaching guidelines were presented to students in the nursing faculty's class room at Zagazig University during this phase. This session consists of a theoretical part that began at 12 p.m. and ended at 2 p.m., with the goal of improving students' knowledge and attitudes about COVID-19. Lectures on the corona virus, its nature, signs and symptoms, risk groups for corona virus disease, mode of transmission, vaccination and treatment, and prevention and self-protection were provided during this phase. On the disease's prevention strategies, the designed guidelines were introduced using power point media, brochures, and images. Following the lectures, students and researchers had an open conversation for about an hour, which included asking questions and receiving responses. The students under study were divided into small groups: about 15 students in every session this was done twice a week for three months, each session lasting 
three hours, two hours for interpretation and one hour for asking and discussing).

Third phase (Evaluation phase): It followed the second stage and was used to evaluate students' progression in terms of knowledge and attitude using tool (1) and Likert Scale-type questions.

\section{Second phase:}

This was started at 12 a.m. on a day other than the theoretical part of the class, with the intention of improving students' personal hygiene and preventive control procedures. It was held in a student's class room at zagzaig University's faculty of nursing for three weeks, once a week, after the theoretical component has been completed. It consisted of three main phases as well (Assessment, Implementation, and Evaluation).

Assessment phase: It aims to evaluate students' level of skill in wearing and removing a face mask and hand washing, as well as assessing students' knowledge of preventive and controlling measures regarding corona virus using tool 2 .

Implementation phase: It aimed to improve students' skills in terms of putting on and removing a face mask, as well as hand washing. Using power points, videos, demonstration and re-demonstration, a session was held about the importance, time frequency, and technique of wearing and removing a face mask and hand wash. It took about 2 hours, after which the students went to the nursing faculty's labs to learn how to wear and remove a face mask, as well as how to wash their hands. Each student performed at least three trials until mastering in the procedure. This is done for two day after the theoretical day each week for 3 consecutive months. Every day, about 4 hours at time span of 12:00 to 4:00 p.m. The students divided into small groups: about 15 students in each session. The students were instructed to follow the protocol until they were proficient at wearing and removing a face mask, as well as hand washing. At the end of the research, each student was given a written handout that included all of the previous instructions that they should follow in their daily lives.

\section{Evaluation phase:}

Using the developed tools, each student was evaluated twice during the study period. The first evaluation took place during the assessment process, and the second evaluation took place shortly after the training was completed. Using an interview form to evaluate the student's knowledge, attitude, and practice of COVID-19.

\section{Statistical analysis:}

All of the collected data was organised, categorised, tabulated, entered, and analysed using SPSS (Statistical Package for Social Sciences) version 20 software. The statistical significance and associations were assessed using, the arithmetic mean, the standard deviation (SD), Pearson chi-square test $\left(\mathrm{X}^{2}\right)$ and Pearson Correlation ( $\mathrm{r}$ ) to detect the relation between the variables. Significance of the result: No significant (NS): If $\mathrm{P}>0.05$, Significant (S): If $\mathrm{P}<$ 0.05 , Highly significant (HS): If $\mathrm{P}<0.01$. 


\section{Results}

Table (1): Number and Percentage Distribution of the studied students according to their Personal characteristics data $(\mathrm{n}=\mathbf{2 8 6})$.

\begin{tabular}{|l|c|c|}
\hline \multicolumn{1}{|c|}{ Personal characteristics data } & No & \% \\
\hline Age (Year) & \multicolumn{2}{c|}{} \\
17 & $\mathbf{1 9 8}$ & 2.1 \\
18 & 82 & $\mathbf{6 9 . 2}$ \\
19 & \multicolumn{2}{|c|}{$\mathbf{1 8 . 2 7 \pm . 4 8 4}$} \\
\hline X S.D & \multicolumn{2}{|c|}{} \\
\hline Sex & $\mathbf{1 4 4}$ & $\mathbf{5 0 . 3}$ \\
Male & 142 & 49.7 \\
Female & & \\
\hline Residence & 207 & $\mathbf{7 2 . 4}$ \\
Rural & 79 & 27.6 \\
Urban & & \\
\hline History of chest disease & 66 & 23.1 \\
Yes & $\mathbf{2 2 0}$ & $\mathbf{7 6 . 9}$ \\
No & & \\
\hline History of immune disease & 16 & 5.6 \\
Yes & $\mathbf{2 7 0}$ & $\mathbf{9 4 . 4}$ \\
No & & \\
\hline Smoking & 20 & 7 \\
Yes & $\mathbf{2 6 0}$ & $\mathbf{9 3}$ \\
\hline No & & \\
\hline Sources of information about COVID 19 & $\mathbf{1 7 1}$ & $\mathbf{5 9 . 8}$ \\
Social media & 47 & 16.4 \\
Radio \& television & 15 & 5.2 \\
Colleagues & 9 & 3.1 \\
Family & 44 & 15.4 \\
\hline All & & \\
\hline
\end{tabular}

Table (2): Comparison between the studied students regarding their knowledge about COVID 19 at pre- and post-teaching guidelines $(n=286)$.

\begin{tabular}{|c|c|c|c|c|c|c|c|c|c|c|}
\hline \multirow{3}{*}{ Items } & \multicolumn{4}{|c|}{$\overline{\text { Pre }}$} & \multicolumn{4}{|c|}{ Post } & \multirow{3}{*}{ T.test } & \multirow{3}{*}{ p-value } \\
\hline & \multicolumn{2}{|c|}{ Satisfactory } & \multicolumn{2}{|c|}{ Unsatisfactory } & \multicolumn{2}{|c|}{ Satisfactory } & \multicolumn{2}{|c|}{ Unsatisfactory } & & \\
\hline & No & $\%$ & No & $\%$ & No & $\%$ & No & $\%$ & & \\
\hline Nature of Corona virus & 104 & 36.4 & 182 & 63.6 & 276 & 96.5 & 10 & 3.5 & 31.79 & $.000 * *$ \\
\hline $\begin{array}{l}\text { Signs and symptoms } \\
\text { associated to corona } \\
\text { virus }\end{array}$ & 25 & 8.7 & 261 & 91.3 & 258 & 90.2 & 28 & 9.8 & 28.53 & $.000 * *$ \\
\hline $\begin{array}{l}\text { Risk group for corona } \\
\text { virus disease }\end{array}$ & 94 & 32.9 & 192 & 67.1 & 280 & 97.9 & 6 & 2.1 & 32.34 & $.000 * *$ \\
\hline Mode of Transmission & 84 & 29.4 & 202 & 70.6 & 280 & 97.9 & 6 & 2.1 & 42.55 & $.000 * *$ \\
\hline $\begin{array}{l}\text { Vaccination and } \\
\text { treatment }\end{array}$ & 43 & 15 & 243 & 85 & 276 & 96.5 & 10 & 3.5 & 38.92 & $.000 * *$ \\
\hline $\begin{array}{l}\text { Preventive Measure } \\
\text { and Self Protection }\end{array}$ & 68 & 23.8 & 218 & 76.2 & 282 & 98.6 & 4 & 1.4 & 29.45 & $.000 * *$ \\
\hline \multirow{2}{*}{$\begin{array}{l}\text { Total } \\
\mathrm{x}^{-} \text {S.D }\end{array}$} & 42 & 14.7 & 244 & 85.3 & 279 & 97.6 & 7 & 2.4 & \multirow[t]{2}{*}{54.37} & \multirow[t]{2}{*}{$.000 * *$} \\
\hline & \multicolumn{4}{|c|}{$12.58 \pm 3.20$} & \multicolumn{4}{|c|}{$25.78 \pm 2.42$} & & \\
\hline
\end{tabular}

**highly significant at $p<0.01$. 
Table (3): Comparison between the studied students regarding their attitude towards COVID 19 at pre- and post-teaching guidelines $(\mathbf{n}=\mathbf{2 8 6})$.

\begin{tabular}{|c|c|c|c|c|c|c|}
\hline \multirow{2}{*}{$\begin{array}{l}\text { Levels of total attitude } \\
\text { regarding COVID } 19\end{array}$} & \multicolumn{2}{|c|}{ Pre } & \multicolumn{2}{|c|}{ Post } & \multirow[b]{2}{*}{ T.test } & \multirow[b]{2}{*}{ p-value } \\
\hline & $\mathbf{N}$ & $\%$ & $\mathbf{N}$ & $\%$ & & \\
\hline Positive & 91 & 31.8 & 282 & 98.6 & \multirow{3}{*}{40.95} & \multirow{3}{*}{$.000 * *$} \\
\hline Negative & 195 & 68.2 & 4 & 1.4 & & \\
\hline X S.D & \multicolumn{2}{|c|}{$8.84 \pm 3.18$} & \multicolumn{2}{|c|}{$17.40 \pm 1.20$} & & \\
\hline
\end{tabular}

**highly significant at $p<0.01$.

Table (4): Comparison between the studied students regarding their reported practices towards COVID 19 at pre- and post-teaching guidlines $(n=286)$.

\begin{tabular}{|c|c|c|c|c|c|c|c|c|c|c|}
\hline \multirow[t]{3}{*}{ Items } & \multicolumn{4}{|c|}{ Pre } & \multicolumn{4}{|c|}{ Post } & \multirow{3}{*}{ T.test } & \multirow{3}{*}{ p-value } \\
\hline & \multicolumn{2}{|c|}{ Satisfactory } & \multicolumn{2}{|c|}{ Unsatisfactory } & \multicolumn{2}{|c|}{ Satisfactory } & \multicolumn{2}{|c|}{ Unsatisfactory } & & \\
\hline & No & $\%$ & No & $\%$ & No & $\%$ & No & $\%$ & & \\
\hline $\begin{array}{l}\text { Preventive measures and } \\
\text { Personal hygiene of corona } \\
\text { virus disease }\end{array}$ & 80 & 28 & 206 & 72 & 281 & 98.3 & 5 & 1.7 & 29.17 & $.000 * *$ \\
\hline Technique of using face mask & 27 & 9.4 & 259 & 90.6 & 286 & 100 & 0 & 0.0 & 52.34 & $.000 * *$ \\
\hline Taking off a face mask & 23 & 8 & 263 & 92 & 286 & 100 & 0 & 0.0 & 54.34 & $.000 * *$ \\
\hline Hand washing & 10 & 3.5 & 276 & 96.5 & 280 & 97.9 & 6 & 2.1 & 63.91 & $.000 * *$ \\
\hline \multirow[t]{2}{*}{ Total } & 20 & 7 & 266 & 93 & 282 & 98.6 & 4 & 1.4 & \multirow{2}{*}{65.54} & \multirow{2}{*}{$.000 * *$} \\
\hline & \multicolumn{4}{|c|}{$12.77 \pm 5.66$} & \multicolumn{4}{|c|}{$37.25 \pm 2.50$} & & \\
\hline
\end{tabular}

**highly significant at $p<0.01$.

Table (5): Relation between students' personal data and their total knowledge about COVID-19 at pre- and postteaching guidelines $(n=286)$.

\begin{tabular}{|c|c|c|c|c|c|c|c|c|c|c|c|c|c|}
\hline \multirow[t]{3}{*}{$\begin{array}{l}\text { Students' } \\
\text { data }\end{array}$} & \multirow[t]{3}{*}{ personal } & \multicolumn{4}{|c|}{$\begin{array}{l}\text { Levels of total } \\
\text { knowledge at pre- } \\
\text { teaching guidlines }\end{array}$} & \multirow[t]{3}{*}{$\overline{\mathrm{X} 2}$} & \multirow[t]{3}{*}{$\begin{array}{c}\text { P- } \\
\text { Value }\end{array}$} & \multicolumn{4}{|c|}{$\begin{array}{l}\text { Levels of total knowledge } \\
\text { at post-teaching guidlines }\end{array}$} & \multirow[t]{3}{*}{$\overline{\mathrm{X} 2}$} & \multirow[t]{3}{*}{\begin{tabular}{|c|} 
P- \\
Value
\end{tabular}} \\
\hline & & \multicolumn{2}{|c|}{\begin{tabular}{|l|} 
Satisfactory \\
\end{tabular}} & \multicolumn{2}{|c|}{ Unsatisfactory } & & & \multicolumn{2}{|c|}{ Satisfactory } & \multicolumn{2}{|c|}{ Unsatisfactory } & & \\
\hline & & \begin{tabular}{|l} 
No \\
\end{tabular} & $\%$ & No & $\%$ & & & No & $\%$ & No & $\%$ & & \\
\hline \multirow{3}{*}{$\begin{array}{l}\text { Age } \\
\text { (year) }\end{array}$} & $17-<19$ & 1 & 16.7 & 5 & \begin{tabular}{|l|}
83.3 \\
\end{tabular} & \multirow[t]{3}{*}{.155} & \multirow[t]{3}{*}{.925} & 6 & 100 & 0 & 0.0 & \multirow[t]{3}{*}{2.900} & \multirow[t]{3}{*}{.235} \\
\hline & $19-<21$ & 28 & 14.1 & 170 & \begin{tabular}{|l|}
85.9 \\
\end{tabular} & & & 195 & 98.5 & 3 & 1.5 & & \\
\hline & $\geq 21$ & 13 & 15.9 & 69 & \begin{tabular}{|l|}
84.1 \\
\end{tabular} & & & 78 & 95.1 & 4 & 4.9 & & \\
\hline \multirow[b]{2}{*}{ Sex } & Male & 15 & 10.4 & 129 & \begin{tabular}{|l|}
89.6 \\
\end{tabular} & \multirow[t]{2}{*}{218} & \multirow[t]{2}{*}{$.040^{*}$} & 140 & 97.2 & 4 & 2.8 & \multirow[t]{2}{*}{.132} & \multirow[t]{2}{*}{.716} \\
\hline & Female & 27 & 19 & 115 & 81 & & & 139 & 97.9 & 3 & 2.1 & & \\
\hline \multirow{2}{*}{ Residence } & Rural & 36 & 17.4 & 171 & 82.6 & \multirow[t]{2}{*}{4.380} & \multirow[t]{2}{*}{$.036^{*}$} & 204 & 98.6 & 3 & 1.4 & \multirow[t]{2}{*}{3.128} & \multirow[t]{2}{*}{.077} \\
\hline & Urban & 6 & 7.6 & 73 & \begin{tabular}{|l|}
92.4 \\
\end{tabular} & & & 75 & 94.9 & 4 & 5.1 & & \\
\hline \multirow{2}{*}{$\begin{array}{l}\text { History of } \\
\text { chest } \\
\text { disease }\end{array}$} & Yes & 38 & 17.3 & 182 & \begin{tabular}{|l|}
82.7 \\
\end{tabular} & \multirow[t]{2}{*}{5.094} & \multirow[t]{2}{*}{$.024 *$} & 216 & 98.2 & 4 & 1.8 & \multirow[t]{2}{*}{1.582} & \multirow[t]{2}{*}{.209} \\
\hline & No & 4 & 6.1 & 62 & \begin{tabular}{|c|}
93.9 \\
\end{tabular} & & & 63 & 95.5 & 3 & 4.5 & & \\
\hline History of & Yes & 41 & 15.2 & 229 & \begin{tabular}{|l|}
84.8 \\
\end{tabular} & .963 & .327 & 264 & 97.8 & 6 & 2.2 & 1.026 & .311 \\
\hline $\begin{array}{l}\text { immune } \\
\text { disease }\end{array}$ & No & 1 & 6.2 & 15 & \begin{tabular}{|l|}
93.8 \\
\end{tabular} & & & 15 & 93.8 & 1 & 6.2 & & \\
\hline Smoking & Yes & 42 & 15.8 & 224 & 84.2 & 3.701 & .054 & 259 & 97.4 & 7 & 2.6 & .540 & .463 \\
\hline Smoking & No & 0 & 0.0 & 20 & 100 & & & 20 & 100 & 0 & 0.0 & & \\
\hline & $\begin{array}{l}\text { Social } \\
\text { media }\end{array}$ & 25 & 14.6 & 146 & 85.4 & 7.832 & .098 & 166 & 97.1 & 5 & 2.9 & 2.512 & .642 \\
\hline $\begin{array}{l}\text { of } \\
\text { informati }\end{array}$ & $\begin{array}{c}\text { Radio \& } \\
\text { television }\end{array}$ & 12 & 25.5 & 35 & 74.5 & & & 45 & 95.7 & 2 & 4.3 & & \\
\hline about & \begin{tabular}{|l} 
Colleagues \\
\end{tabular} & 1 & 6.7 & 14 & \begin{tabular}{|l|}
93.3 \\
\end{tabular} & & & 15 & 100 & $\overline{0}$ & 0.0 & & \\
\hline covid 19 & Family & 0 & 0.0 & 9 & 100 & & & 9 & 100 & 0 & 0.0 & & \\
\hline & All & 4 & 9.1 & 40 & \begin{tabular}{|c|}
90.9 \\
\end{tabular} & & & 44 & 100 & 0 & 0.0 & & \\
\hline
\end{tabular}

No significant at $p>0.05$.

* significant at $p<0.05$. 
Table (6): Relation between students' personal data and their total attitude towards COVID-19 at pre- and postteaching guidelines $(n=286)$.

\begin{tabular}{|c|c|c|c|c|c|c|c|c|c|c|c|c|c|}
\hline \multirow{3}{*}{\multicolumn{2}{|c|}{$\begin{array}{c}\text { Students' personal } \\
\text { data }\end{array}$}} & \multicolumn{4}{|c|}{$\begin{array}{l}\text { Levels of total attitude at } \\
\text { pre-teaching guidlines }\end{array}$} & \multirow[t]{3}{*}{$\mathrm{X} 2$} & \multirow{3}{*}{$\begin{array}{c}\text { P- } \\
\text { Value }\end{array}$} & \multicolumn{4}{|c|}{$\begin{array}{l}\text { Levels of total attitude at } \\
\text { post-teaching guidlines }\end{array}$} & \multirow[t]{3}{*}{$\mathbf{X} 2$} & \multirow{3}{*}{$\begin{array}{c}\text { P- } \\
\text { Value }\end{array}$} \\
\hline & & \multicolumn{2}{|c|}{ Positive } & \multicolumn{2}{|c|}{ Negative } & & & \multicolumn{2}{|c|}{ Positive } & \multicolumn{2}{|c|}{ Negative } & & \\
\hline & & No & $\%$ & No & $\%$ & & & No & $\%$ & No & $\%$ & & \\
\hline \multirow{3}{*}{$\begin{array}{l}\text { Age } \\
\text { (year) }\end{array}$} & $17-<19$ & 4 & 66.7 & 2 & 33.3 & \multirow{3}{*}{4.393} & \multirow{3}{*}{.111} & 6 & 100 & 0 & 0.0 & \multirow[t]{3}{*}{.945} & \multirow[t]{3}{*}{.623} \\
\hline & $19-<21$ & 65 & 32.8 & 133 & 67.2 & & & 196 & 99 & 2 & 1 & & \\
\hline & $\geq 21$ & 22 & 26.8 & 60 & 73.2 & & & 80 & 97.6 & 2 & 2.4 & & \\
\hline \multirow{2}{*}{ Sex } & Male & 33 & 22.9 & 111 & 77.1 & \multirow{2}{*}{10.59} & \multirow{2}{*}{$.001 * *$} & 143 & 99.3 & 1 & 0.7 & \multirow{2}{*}{$\begin{array}{c}1.04 \\
3\end{array}$} & \multirow[t]{2}{*}{.307} \\
\hline & Female & 58 & 40.8 & 84 & 59.2 & & & 139 & 97.9 & 3 & 2.1 & & \\
\hline \multirow{2}{*}{ Residence } & Rural & 76 & 36.7 & 131 & 63.3 & \multirow{2}{*}{8.283} & \multirow{2}{*}{$.004 * *$} & 205 & 99 & 2 & 1 & \multirow{2}{*}{$\begin{array}{c}1.01 \\
6\end{array}$} & \multirow[t]{2}{*}{.313} \\
\hline & Urban & 15 & 19 & 64 & 81 & & & 77 & 97.5 & 2 & 2.5 & & \\
\hline \multirow{2}{*}{$\begin{array}{l}\text { History of } \\
\text { chest } \\
\text { disease }\end{array}$} & Yes & 82 & 37.3 & 138 & 62.7 & \multirow[b]{2}{*}{13.07} & \multirow[b]{2}{*}{$.000 * *$} & 217 & 98.6 & 3 & 1.4 & \multirow[t]{2}{*}{.008} & \multirow[t]{2}{*}{.927} \\
\hline & No & 9 & 13.6 & 57 & 86.4 & & & 65 & 98.5 & 1 & 1.5 & & \\
\hline \multirow{2}{*}{$\begin{array}{l}\text { History of } \\
\text { immune } \\
\text { disease }\end{array}$} & Yes & 89 & 33 & 181 & 67 & & & 266 & 98.5 & 4 & 1.5 & .240 & .624 \\
\hline & No & 2 & 12.5 & 14 & 87.5 & 2.915 & .088 & 16 & 100 & 0 & 0.0 & & \\
\hline Smoking & Yes & 88 & 33.1 & 178 & 66.9 & 2.804 & 094 & 262 & 98.5 & 4 & 1.5 & .305 & .581 \\
\hline SmOKIng & No & 3 & 15 & 17 & 85 & 2.004 & .094 & 20 & 100 & 0 & 0.0 & & \\
\hline Sources & $\begin{array}{l}\text { Social } \\
\text { media }\end{array}$ & 55 & 32.2 & 116 & 67.8 & & & 169 & 98.8 & 2 & 1.2 & .830 & .934 \\
\hline $\begin{array}{l}\text { of } \\
\text { informati }\end{array}$ & $\begin{array}{c}\text { Radio \& } \\
\text { television } \\
\end{array}$ & 17 & 36.2 & 30 & 63.8 & 2.568 & .632 & 46 & 97.9 & 1 & 2.1 & & \\
\hline on about & Colleagues & 6 & 40 & 9 & 60 & & & 15 & 100 & 0 & 0.0 & & \\
\hline covid 19 & Family & 3 & 33.3 & 6 & 66.7 & & & 9 & 100 & 0 & 0.0 & & \\
\hline & All & 10 & 22.7 & 34 & 77.3 & & & 43 & 97.7 & 1 & 2.3 & & \\
\hline
\end{tabular}

Table (7): Relation between students' personal data and their total reported practices towards COVID-19 at preand post-teaching guidlines $(n=286)$.

\begin{tabular}{|c|c|c|c|c|c|c|c|c|c|c|c|c|c|}
\hline \multirow{3}{*}{\multicolumn{2}{|c|}{$\begin{array}{c}\text { Students' personal } \\
\text { data }\end{array}$}} & \multirow{2}{*}{\multicolumn{4}{|c|}{$\begin{array}{l}\text { Levels of total reported } \\
\text { practices at pre-teaching } \\
\text { guidlines } \\
\text { Satisfactory Unsatisfactory }\end{array}$}} & \multirow[t]{3}{*}{$\mathrm{X} 2$} & \multirow{3}{*}{$\begin{array}{c}\text { P- } \\
\text { Value }\end{array}$} & \multicolumn{4}{|c|}{$\begin{array}{l}\text { Levels of total reported } \\
\text { practices at post-teaching } \\
\text { guidlines }\end{array}$} & \multirow[t]{3}{*}{$\mathbf{X} 2$} & \multirow{3}{*}{$\begin{array}{c}\text { P- } \\
\text { Value }\end{array}$} \\
\hline & & & & & & & & \multicolumn{2}{|c|}{ Satisfactory } & \multicolumn{2}{|c|}{ Unsatisfactory } & & \\
\hline & & No & $\%$ & No & $\%$ & & & No & $\%$ & No & $\%$ & & \\
\hline \multirow{3}{*}{ Age (year) } & $17-<19$ & 1 & 16.7 & 5 & 83.3 & \multirow{3}{*}{.932} & \multirow{3}{*}{.627} & 6 & 100 & 0 & 0.0 & \multirow{3}{*}{.124} & \multirow{3}{*}{.940} \\
\hline & $19-<21$ & 13 & 6.6 & 185 & 93.4 & & & 195 & 98.5 & 3 & 1.5 & & \\
\hline & $\geq 21$ & 6 & 7.3 & 76 & 92.7 & & & 81 & 98.8 & 1 & 1.2 & & \\
\hline \multirow{2}{*}{ Sex } & Male & 13 & 9 & 131 & 91 & \multirow{2}{*}{1.846} & \multirow{2}{*}{.174} & 142 & 98.6 & 2 & 1.4 & \multirow{2}{*}{.000} & \multirow{2}{*}{.989} \\
\hline & Female & 7 & 4.9 & 135 & 95.1 & & & 140 & 98.6 & 2 & 1.4 & & \\
\hline \multirow{2}{*}{ Residence } & Rural & 15 & 7.2 & 192 & 92.8 & \multirow{2}{*}{.074} & \multirow{2}{*}{.786} & 204 & 98.6 & 3 & 1.4 & \multirow{2}{*}{.014} & \multirow{2}{*}{.906} \\
\hline & Urban & 5 & 6.3 & 74 & 93.7 & & & 78 & 98.7 & 1 & 1.3 & & \\
\hline \multirow{2}{*}{$\begin{array}{l}\text { History of } \\
\text { chest } \\
\text { disease }\end{array}$} & Yes & 18 & 6.7 & 202 & 93.3 & \multirow{2}{*}{2.072} & \multirow{2}{*}{.150} & 216 & 98.2 & 4 & 1.8 & \multirow{2}{*}{1.217} & \multirow{2}{*}{.270} \\
\hline & No & 2 & 3 & 64 & 97 & & & 66 & 100 & 0 & 0.0 & & \\
\hline \multirow{2}{*}{$\begin{array}{l}\text { History of } \\
\text { immune } \\
\text { disease }\end{array}$} & Yes & 18 & 6.7 & 252 & 93.3 & \multirow[b]{2}{*}{.790} & \multirow[b]{2}{*}{.374} & 266 & 98.5 & 4 & 1.5 & & \\
\hline & No & 2 & 12.5 & 14 & 87.5 & & & 16 & 100 & 0 & 0.0 & 240 & .624 \\
\hline & Yes & 18 & 6.8 & 248 & 93.2 & & & 262 & 98.5 & 4 & 1.5 & & 581 \\
\hline Smoking & No & 2 & 10 & 18 & 90 & .299 & . 585 & 20 & 100 & 0 & 0.0 & .300 & .501 \\
\hline & $\begin{array}{l}\text { Social } \\
\text { media }\end{array}$ & 13 & 7.6 & 158 & 92.4 & & & 169 & 98.8 & 2 & 1.2 & & \\
\hline $\begin{array}{l}\text { Sources of } \\
\text { informatio }\end{array}$ & $\begin{array}{c}\text { Radio \& } \\
\text { television }\end{array}$ & 4 & 8.5 & 43 & 91.5 & 2.071 & .723 & 46 & 97.9 & 1 & 2.1 & 7.239 & .124 \\
\hline $\mathrm{n}$ about & Colleagues & 0 & 0.0 & 15 & 100 & & & 15 & 100 & 0 & 0.0 & & \\
\hline & Family & 0 & 0.0 & 9 & 100 & & & 8 & 88.9 & 1 & 11.1 & & \\
\hline & All & 3 & 6.8 & 41 & 93.2 & & & 44 & 100 & 0 & 100 & & \\
\hline
\end{tabular}

No significant at $p>0.05$. 
Table (8): Correlation between students' knowledge, attitude and their reported practice towards first aid measures at pre- and post-teaching guidlines

\begin{tabular}{|c|c|c|c|c|c|}
\hline \multirow{2}{*}{\multicolumn{2}{|c|}{ Variables }} & \multicolumn{2}{|c|}{ Total knowledge } & \multicolumn{2}{|c|}{ Total attitude } \\
\hline & & Pre & Post & Pre & Post \\
\hline Total attitude & $\begin{array}{l}\mathbf{R} \\
\mathbf{P}\end{array}$ & $\begin{array}{c}.295 \\
.000 * *\end{array}$ & $\begin{array}{c}.737 \\
.000^{* *}\end{array}$ & & \\
\hline $\begin{array}{l}\text { Total reported } \\
\text { practice }\end{array}$ & $\begin{array}{l}\mathbf{R} \\
\mathbf{P}\end{array}$ & $\begin{array}{c}.159 \\
.007 * *\end{array}$ & $\begin{array}{c}.688 \\
.000 * *\end{array}$ & $\begin{array}{c}.168 \\
.004 * *\end{array}$ & $\begin{array}{l}.713 \\
.000 * *\end{array}$ \\
\hline
\end{tabular}

**highly significant at $p<0.01$.

Table (1): Shows that more than half of the studied students are male $(50.3 \%)$ with mean age of $\mathbf{1 8 . 2 7} \pm$ .484. more than three quarters $(76.9 \%)$ have no previous history of chest disease. While (72.4\%) of studied students come from rural area and Urban area (27.6\%). Most of studied students $(94.4 \%$ and $93.0 \%)$ have no history of immune disease and smoking habits. The main source of information about Covid19 is social media $(59.8 \%)$ followed by Radio and television (16.4\%).

Table (2): Reveals that the majority $(85.3 \%)$ of the studied students have unsatisfactory of their total knowledge before implementation of teaching guidelines. Though there are statistically significant differences in their knowledge following implementation of teaching guidelines $(\mathrm{P}=000)$, all students have satisfactory knowledge in almost all areas of their total knowledge

Table (3): The most of the studied students (98.6\%) have positive attitude regarding Covid-19 after implementation of teaching guidelines compared to $(68.2 \%)$ of them have negative attitude before guidelines. There is highly statistically significant difference between pre/post implementation of teaching guidelines to the first year nursing student's attitude regarding Covid-19( $\mathrm{P}=\mathbf{0 0 0})$.

Table (4): Points to highly statistically significant improvement in student's practice regarding Covid-19 between pre/post implementation of teaching guidelines. Hand washing have the lowest levels of satisfied practice prior to the guidelines $(3.5 \%)$. At the pre-assessment, $(7.0 \%)$ of the students have overall satisfactory practices, which increased to $(97.9 \%)$ and $(98.6 \%)$ at the post-assessment, respectively.

Table (5): Displays the relation between students' personal data and their total knowledge about Covid19. There are statistically significant differences between their total knowledge and personal data (sex, residence, and history of chest disease) pre teaching guidelines $(.040, .036,024)$, while there is no statistically significant difference between them post implementation of teaching guidelines.

Table (6): Indicates that there is statistically significant difference between students' personal data (sex, residence, and history of chest disease) and their total attitude toward COVID -19 before implementation of teaching guidelines (.001, 004, $.000)$. After teaching guidelines, there is no statistically significant difference between them.

Table (7): Relation between students' personal data and their total practices toward Covid-19 pre - post teaching guidelines. It is found that there are no statistical significant differences between students' personal data and their total practices.

Table (8): Identifies that there is a strong positive correlation between total students' knowledge, attitude, and their reported practice toward Covid-19 with highly statistically significant differences $(\mathrm{P}=$ 000).

\section{Discussion}

Various factors, such as the gravity of the infection, the magnitude of its spread, and the fatality rate, can affect people's knowledge, attitudes, and practices about a specific infectious disease. World Health Organization (WHO) has declare COVID -19 a pandemic by the. COVID -19 knowledge, attitudes, and practices have been increasing day by day (Alzoubi, et al, 2020).

The present study revealed that more than half of studied students were male and the age of them ranged from 17-19 years old. This study disagreement with Dafni \& Maddalena (2020) who found in their study about" Knowledge, attitude and practice of secondary school students toward Covid-19 epidemic in Italy" that age of the participants ranged from 14 to 19 years old and that more than half of the participants were females.

According to the present study, social media was the primary source of knowledge about COVID-19. This may be attributed to the recent widespread of the internet, which has led to the majority of college students being internet users and using the internet as a primary source of information. The findings were backed up by a study conducted by Hamaza, et al., (2020) in their cross- sectional study on awareness and knowledge of COVID-19 among senior pharmacy students. 
In terms of subject knowledge prior to and after the implementation of teaching guidelines, the current study discovered that students' knowledge improved with a highly statistically significant difference in post-assessment versus pre-assessment.. This may be due to the giving program which included lectures about COVID-19, and booklet which highlighted all knowledge gaps regarding COVID-19 among studied students. This finding in line with Pen, et al.,(2020) who found in their study about" Across sectional survey of knowledge, Attitude, and Practice Associated with COVID-19 among under graduated students in China" that students showed a good score of knowledge which could be explained by their training in clinical nursing and public health.

In terms of change in students' attitudes toward COVID-19, there was a positive attitude toward COVID-19 in post-assessment relative to preassessment, which was highly statistically significant. This may be because the program uses of a variety of methods for explanation, discussion, and responding to all of the students' concerns regarding COVID-19 prevention and protection measures. The high-risk group for infection, as well as the researcher's correction and clarification of a number of erroneous assumptions and ideas about the nature of virus, the most common cause of infection, vaccination, transmission methods, and preventive methods for the students. These findings are in line with Okoro, et al.,(2020) who indicated in their study about" Attitude and preventive practices toward COVID19diseases" our participants generally had appositive attitude regarding COVID-19.

Regarding students practice toward COVID-19, there was a highly statistically significant improvement among students after implementation of teaching guidelines. This may be due to the practical session that was provided toward preventive measures and personal hygiene of corona virus disease, technique of wearing and taking off mask and hand washing. This finding was consistent with a study conducted by AbdHasan (2021), which found that the majority of students used precautionary measures to manage COVID-19 spread, indicating that they had good practice.

Concerning correlation between knowledge, attitude, and practice pre -post the present study found that statistically significant positive correlation between knowledge, attitude, and practice post implementation of teaching guidelines. This may be due to the program's success in improving students' knowledge, attitude, and practice of COVID-19. This result is consistent with Saqlain, et al., (2020), who found a statistically significant correlation between studied sample knowledge, attitude, and practice score in their study.

\section{Conculsion}

The study concluded that there was a strong positive correlation between total student's knowledge, attitude, and their reported practice regarding COVID-19 with highly statistically significant differences $(\mathrm{P}=000)$.

\section{Recommendation}

- Application of the current Coronavirus preventive health programs in all other Egyptian nursing faculties to enhance their knowledge and attitude.

- Coronavirus preventive health programmes should provide basic details about the disease, its symptoms in humans, as well as simple practical protection measures and good hygiene practises.

- Further studies are recommended on all categories pertaining to the prevention and treatment of respiratory tract infectious diseases.

\section{Author contribution:}

The two authors contributed to conception of the research, the development of the tools, statistical analysis, and commentary on the tables, writing the discussion and references, preparing the training program and collecting data and reference.

Financial support: No funding was received.

Conflict of interest: No

\section{References}

- AbdHasan. (2021): Knowledge, Attitudes, and Practices of King Abdulaziz undergraduate Nursing toward Novel Corona Virus (COVID-19). Health Sci-J :15(1) 1-5. Available at: www.imedpub.com.

- Alshdefat, A. (2021): Knowledge, Attitude, and Practices Towards COVID 19 Panademic in Oman. International Journal of Nursing Education. 13(1) 23-33. Available at:http://www. researchgate.net/publication/348162879.

- Alzoubi, H. (2020): Covid-19 - Knowledge, Attitudes, and Practices among Medical and Non Medical universities students in Jordan, J-Pure APPL-Microbiology 14(1) 17-24. Available at: https://www.researchgate.net/publication/34041951 9.

- Chen, N. (2020): Epidemiological and clinical characteristics of 99 cases of 2019 novel coronavirus pneumonia in Wuhan, China: a descriptive study. The Lancet. 395(10223): 507513. Available at: https://doi.org/10.1016/S01406736(20)30211-7.Accessed on 1December,2020 at 5PM.

- Dafni, S. \& Maddalena, D. (2020): Knowledge, attitude and practice of secondary school students toward Covid-19 epidemic in Italy: across selectional study. Available at: https://www.researchgate.net/deref/http\%3A\%2 
F\%2Fdx.doi.org\%2F10.1101\%2F2020.05.08.084 236. Accessed on 15 December, 2020.at 4 AM.

- Dean, Andrew G, Dean, Jeffrey A, Burton, Anthony H, Dicker, Richard C, \& Coulombier, Denis. (1995). Epi Info : a word-processing, database, and statistics program for public health on IBM-compatible microcomputers. Atlanta, Georgia: Centers for Disease Control and Prevention. https://apps. who.int/iris/handle/10665/6 2836

- Hamaza, M S. (2020): Cross- Sectional Study on Awareness and Knowledge of COVID-19 Among Senior Pharmacy Students. J Community Health. 46(1):139-146.

- Ministry of Health and Population Egypt"MOHP"(2020): Covid-19 in Egypt, Available at http://www.care.gov.eg/Egypt care/index.aspx.Accesses on 20 December,2020 at 9 PM.

- Ministry of Health Guidelines (2020): Guidelines on Prevention and Control COVID19. Available at https://www.health.go.ug/covid/project/guidelines/ accessed on 10 October, 2020. At 5 P.M.

- Nassef, H. (2020): Knowledge, Attiudes, and Practices about Coronavirus disease (COVID-19) among Birzeit University Students: Across sectional study. Research Square. Available at: http://doi.org/10.21203/65.3.rs-83268. Accessed on 1 January 2020. At 7 PM

- Okoro, J. (2020): Attitude and Preventive Practices Toward COVID-19 disease and the Impact of Awareness Training on Knowledge of the Disease Among Correctional Officier. Emerald Open Research, 2(51) 1-12.

- Pen, Y. (2020): Across sectional survey of knowledge, Attitude, and Practice Associated with COVID-19 among under graduated students in China. BMC Public Health, 1292(20):1-8.

- Saqlain, M. (2020): Knowledge, Attitude, and Practice among health care Professionals regarding COVID-19: Across - sectional Survey from Pakistan. Elsevier Ltd 105(3): 419-423.

- World Health Organization (2020): Declares novel coronavirus (2019-nCoV) sixth public health emergency of international concern. Euro surveillance: bulletin Europeen sur les maladies transmissibles $=$ European communicable disease bulletin; 25(5). Available at: https://www.ncbi.nlm.nih.gov/pmc/articles/PMC70 14669/

- World Health Organization (2020): Rational use of personal protective equipment for coronavirus disease (COVID-19) and considerations during severe shortages: interim guidance, 6 April 2020. World Health Organization; 2020.
Available at:

https://apps.who.int/iris/bitstream/handle/ 10665/331215/WHO-2019-nCov-IPCPPE_use2020.1-eng pdf.

- World Health Organization (2021): COVID-19 Cases Worldwide as of May31, 2021, Available at https://covid19.who.int/ https://www.statista.com/statistics/1043366/novel -coronavirus-2019ncov-cases-worldwide-bycountry/.Accessed on 1 May, 2021.At 5 A.M

- World Health Organization (2021): Egypt WHO coronavirus disease(Covid-19)Dashboard. Available at: https://covid19.who.int/region/emro/country/eg. Accessed on 10 January 2021. At 5 AM.

- Zannatul, F. (2020): Knowledge, Attitudes and Practices Regarding Covid19 outbreak in Bangladesh: An online-based cross- sectional studyPlos One Journal, 15(10):1-29.

- Zhang, J. (2020) Risk factors for disease severity, unimprovement,

and mortality in COVID-19 patients in Wuhan, China. Clinical Microbiology and Infection; 26(6): 767-772. 